Vol. 44, N. 2 : pp. 149 - 153, June, 2001

ISSN 1516-8913 Printed in Brazil

AN INTERNATIONAL JOURNAL

\title{
Reduction of Exchangeable Calcium and Magnesium in Soil with Increasing pH
}

\author{
Mário Miyazawa, Marcos A. Pavan *, Cláudio O. Ziglio and Júlio C. Franchini \\ Instituto Agronômico do Paraná (IAPAR). Caixa Postal 481, CEP 86001-970, Londrina - PR, Brasil
}

\begin{abstract}
A laboratory study was conducted with soil samples and synthetic solutions to investigate possible mechanisms related with reduction in $\mathrm{KCl}$ exchangeable $\mathrm{Ca}$ and $\mathrm{Mg}$ with increasing $\mathrm{pH}$. Increasing soil $\mathrm{pH}$ over 5.3 with $\mathrm{CaCO}_{3}$ added to the soil and with $\mathrm{NaOH}$ solution added to soil/KCl suspension increased adsorptions of $\mathrm{Ca}$ and $\mathrm{Mg}$. The reduction of $\mathrm{Mg}$ was greater than $\mathrm{Ca}$ and was related to the concentration of soil exchangeable Al. The decreases of soluble $\mathrm{Ca}$ and $\mathrm{Mg}$ following addition of $\mathrm{Al}$ in synthetic solution were at $\mathrm{pH}>7.5$. The isomorphic coprecipitation reaction with Al compounds may be the most possible mechanism responsible for the decrease of exchangeable Ca and Mg with increasing $\mathrm{pH}$. Possible chemical reactions are presented.
\end{abstract}

Key words: Coprecipitation, aluminum, liming, acid soils

\section{INTRODUCTION}

Soil acidity is of major concern in cropping, horticulture, and pasture production in Brazil. Lime applications have proved to be efficient in ameliorating soil acidity. However, high rates of $\mathrm{CaCO}_{3}, \mathrm{Ca}(\mathrm{OH})_{2}$ or $\mathrm{CaO}$ caused reduction in soil exchangeable $\mathrm{Mg}\left(\mathrm{Mg}_{\mathrm{ex}}\right)$ resulting in plant nutritional unbalanced (Farina et al., 1980; Grove \& Sumner, 1985; Myers et al., 1988). Laboratory studies conducted with soil column showed that although additions of $\mathrm{CaCO}_{3}$ increased $\mathrm{Mg}$ concentration in the drainage water, the total amount of $\mathrm{Mg}$ leached was less than the amount of Mg reduced in soil (Pavan et al., 1984; Pavan \& Roth, 1992). Field studies in apple orchard showed that lime reduced leaf-Mg and fruit yields (Pavan, 1992, 1997). The reduction in $\mathrm{Mg}_{\mathrm{ex}}$ has been attributed to the exchangeable reaction between $\mathrm{Ca}$ and $\mathrm{Mg}$ following by $\mathrm{Mg}$ leaching out of the root zone.

Kinniburgh et al. (1976), Chan et al. (1979), Grove et al. (1981), Grove \& Sumner (1985), and Myers et al. (1988) also found that lime reduced $\mathrm{Mg}_{\mathrm{ex}}$ and suggested that other mechanisms are involved in $\mathrm{Mg}$ reduction than a simple leaching process. They identified three possible mechanisms for the effect of lime on $\mathrm{Mg}$ reduction. In summary these include (1) $\mathrm{Mg}$ adsorption in the inter layers of $\mathrm{Al}(\mathrm{OH})_{3}$ (Kinniburgh et al., 1976); coprecipitation of $\mathrm{Mg}$ as $\mathrm{MgAl}(\mathrm{OH})_{\mathrm{n}}$ (Kinnburgh et al., 1976); and (3) adsorption of $\mathrm{MgOH}^{+}$in the stern layer (Chan et al., 1979).

The objective of this study was to determine the possible mechanisms related to $\mathrm{Mg}_{\mathrm{ex}}$ and $\mathrm{Ca}_{\mathrm{ex}}$ reductions in Brazilian soils with increasing $\mathrm{pH}$.

* Author for correspondence 


\section{MATERIAL AND METHODS}

Three experiments were conducted with soil samples collected from the $0-20 \mathrm{~cm}$ horizon. The soil samples were air dried and ground to pass through a $2 \mathrm{~mm}$ screen before being treated. Table 1 shows the chemical characteristics of the soils. Soils 1, 2, 3, 4, 5 and 6 were LEd, PV, LEd, TRd, LRd, and LRd, respectively, in according with brazilian soil classification.

Table 1 - Chemical characteristics of the soils.

\begin{tabular}{cccccc}
\hline Soil & $\mathrm{pH}$ & $\mathrm{Ca}$ & $\mathrm{Mg}$ & $\mathrm{Al}$ & $\mathrm{C}$ \\
\cline { 3 - 5 } $\mathrm{N}^{\mathrm{o}}$ & $\mathrm{CaCl}_{2}$ & \multicolumn{3}{c}{$\mathrm{Cmol}_{\mathrm{c}} \mathrm{kg}^{-1}$} & $\mathrm{mg} \mathrm{kg}^{-1}$ \\
\hline 1 & 4.0 & 2.48 & 0.58 & 2.79 & 37.5 \\
2 & 3.8 & 0.36 & 0.12 & 1.10 & 7.4 \\
3 & 4.4 & 3.71 & 0.82 & 0.75 & 17.5 \\
4 & 4.3 & 2.42 & 1.23 & 1.88 & 41.2 \\
5 & 4.0 & 1.47 & 0.94 & 1.83 & 25.5 \\
6 & 4.0 & 2.10 & 0.78 & 2.68 & 27.0 \\
\hline
\end{tabular}

Soil incubation with lime: Three soil samples (soils1, 2, and 3, Table 1) were used for this study. One kg of soil sample was incubated in plastic bag with $\mathrm{CaCO}_{3}$ for $120 \mathrm{~d}$, moistened to field capacity $(0.01 \mathrm{MPa})$ at room temperature. Lime rates were $0.0,0.25,0.50,1.0$, and 2.0 times the amount of total acidity $(\mathrm{H}+\mathrm{Al})$ extracted by $1 \mathrm{~mol} \mathrm{~L}^{-1}$ $\mathrm{Ca}\left(\mathrm{C}_{2} \mathrm{H}_{3} \mathrm{O}_{2}\right)_{2}$ at $\mathrm{pH}$ 7. Following incubation, soil $\mathrm{pH}$ was measured in $0.01 \mathrm{M} \quad \mathrm{CaCl}_{2} \quad(1: 2.5$ soil:solution ratio) after shaking for $1 \mathrm{~h} ; \mathrm{Ca}_{\mathrm{ex}}, \mathrm{Mg}_{\mathrm{ex}}$, and $\mathrm{Al}_{\mathrm{ex}}$ were extracted with $1 \mathrm{~mol} \mathrm{~L}^{-1} \mathrm{KCl}$ solution in a 1:10 soil:solution ratio and 10 minutes shaking time. Al was determined by titration with standardized $0.015 \mathrm{~mol} \mathrm{~L}^{-1} \mathrm{NaOH}$ solution using bromotymol blue indicator and $\mathrm{Ca}$ and $\mathrm{Mg}$ determined by atomic absorption spectroscopy. The treatments were replicated three times in a completly randomized block design.

\section{Addition of $\mathrm{NaOH}$ in $\mathrm{KCl}$ soil suspension:}

Three soil samples (soils 4, 5, and 6, Table 1) were used for this study. The procedure was as the following: $5 \mathrm{~g}$ of soil sample was transferred to $100 \mathrm{ml}$ flask; $40 \mathrm{ml}$ of $1 \mathrm{~mol}$

$\mathrm{L}^{-1} \mathrm{KCl}$ solution was added; $\mathrm{pH}$ was adjusted daily to $4,5,7$, and 8 with $\mathrm{NaOH}$ solution for $7 \mathrm{~d}$. Then, the solution volume was diluted to $50 \mathrm{ml}$ with $1 \mathrm{~mol} \mathrm{~L}^{-1} \mathrm{KCl}$ and $\mathrm{pH}, \mathrm{Ca}, \mathrm{Mg}$, and $\mathrm{Al}$ were determined in solution by the same procedures described above.

Effect of Al on Ca and Mg: Ten of $2 \times 10^{-3} \mathrm{~mol}$ $\mathrm{L}^{-1} \mathrm{Mg} \mathrm{Cl}_{2}$ solution was transferred to $60 \mathrm{ml}$ glass flask and added $10 \mathrm{ml}$ of $0,1,2$, and $4 \times 10^{-3} \mathrm{~mol}$ $\mathrm{L}^{-1} \mathrm{AlCl}_{3}$ solution. The solution $\mathrm{pH}$ was adjusted daily to $4,5,6,7$, and 8 with $\mathrm{NaOH}$ solution for $3 \mathrm{~d}$. For adjusting $\mathrm{pH}$, solution was shaked with magnetic bars and boiled with $\mathrm{N}_{2}$ gas at a flow rate of $100 \mathrm{ml} \mathrm{min}^{-1}$ to avoid adsorption of atmospheric $\mathrm{CO}_{2}$ by the solution. Then, the solution volume was diluted to $40 \mathrm{ml}$ with deionized water and rested for 3d. Following resting period $\mathrm{Mg}$ was determined in solution by atomic adsorption spectroscopy. Similar study was conducted with 2 x $10^{-3} \mathrm{~mol} \mathrm{~L}^{-1} \mathrm{CaCl}_{2}$ solution.

\section{RESULTS}

Soil incubation with lime: Table 2 shows the effect of soil incubation with $\mathrm{CaCO}_{3}$ on $\mathrm{pH}, \mathrm{Ca}_{\mathrm{ex}}$, $\mathrm{Mg}_{\mathrm{ex}}$, and $\mathrm{Al}_{\mathrm{ex}}$. Lime to $\mathrm{pH}>5.8$ reduced $\mathrm{Mg}_{\mathrm{ex}}$. At $\mathrm{pH}$ near to neutrality, the reduction in $\mathrm{Mg}_{\mathrm{ex}}$ was 93, 67, and 55\% for soils 1,2 , and 3, respectively. This reduction was related to the initial $\mathrm{Al}_{\mathrm{ex}}$ content (Table 1). The higher the $\mathrm{Al}_{\mathrm{ex}}$, the greater the $\mathrm{Mg}_{\text {ex }}$ reduction. The reduction of $\mathrm{Mg}_{\mathrm{ex}}$ at $\mathrm{pH}<$ 5.0 was minimal, corroborating data presented in previous study with Brazilian soils (Quaggio et al., 1982).

Increasing $\mathrm{CaCO}_{3}$ rates up to $\mathrm{pH} 4.9$ increased $\mathrm{Ca}_{\mathrm{ex}}$ (Table 2). The reduction in $\mathrm{Ca}_{\mathrm{ex}}$ increased with increasing $\mathrm{CaCO}_{3}$ rates. For example, for 2.0 times $\mathrm{H}+\mathrm{Al}$ rate, $\mathrm{Ca}_{\mathrm{ex}}$, reduced to 55, 69, and $83 \%$ for soils 1,2 , and 3 , respectively. At the highest $\mathrm{CaCO}_{3}$ rate the reduction in $\mathrm{Mg}_{\text {ex }}$ was higher than $\mathrm{Ca}_{\mathrm{ex}}$. 
Table 2 - Exchangeable $\mathrm{Ca}, \mathrm{Mg}$, and $\mathrm{Al}$ and $\mathrm{pH}$ after soil incubation with $\mathrm{CaCO}_{3}$

\begin{tabular}{cccccc}
\hline Soil & $\mathrm{pH}$ & $\begin{array}{c}\mathrm{Rates} \\
\mathrm{CaCO}_{3}\end{array}$ & $\mathrm{Ca}$ & $\mathrm{Mg}$ & $\mathrm{Al}$ \\
\cline { 3 - 6 } $\mathrm{N}^{\mathrm{o}}$ & $\mathrm{CaCl}_{2}$ & $\%(\mathrm{H}+\mathrm{Al})$ & \multicolumn{3}{c}{$\mathrm{Cmol}_{\mathrm{c} g} \mathrm{~kg}^{-1}$} \\
\hline 1 & 4.0 & 0.0 & 2.48 & 0.58 & 2.79 \\
& 4.5 & 25 & 6.78 & 0.61 & 0.85 \\
& 4.9 & 50 & 10.21 & 0.53 & 0.08 \\
& 5.8 & 100 & 16.25 & 0.32 & 0.0 \\
& 7.1 & 200 & 21.45 & 0.04 & 0.0 \\
\hline 2 & 3.9 & 0.0 & 0.36 & 0.12 & 1.10 \\
& 4.3 & 25 & 1.77 & 0.12 & 0.40 \\
& 4.8 & 50 & 3.15 & 0.12 & 0.04 \\
& 6.0 & 100 & 5.53 & 0.08 & 0.0 \\
& 7.0 & 200 & 7.77 & 0.04 & 0.00 \\
\hline 3 & 4.1 & 0.0 & 3.71 & 0.82 & 0.75 \\
& 4.4 & 25 & 5.94 & 0.83 & 0.16 \\
& 4.9 & 50 & 7.87 & 0.81 & 0.0 \\
& 5.9 & 100 & 12.11 & 0.74 & 0.0 \\
& 7.2 & 200 & 18.32 & 0.36 & 0.00 \\
\hline
\end{tabular}

\section{Addition of $\mathrm{NaOH}$ in $\mathrm{KCl}$ soil suspension:}

Figure 1 shows the effect of $\mathrm{pH}$ on the concentration of $\mathrm{Ca}, \mathrm{Mg}$, and $\mathrm{Al}$ in $\mathrm{KCl}$ suspension for the three soils. Increasing $\mathrm{pH}$ decreased $\mathrm{KCl}$ exchangeable $\mathrm{Mg}$. The reduction in $\mathrm{KCl}-\mathrm{Mg}$ at $\mathrm{pH} 7.3$ was an average of $49 \%$ for the three soils. Increasing $\mathrm{pH}$ also decreased $\mathrm{KCl}$ exchangeable $\mathrm{Ca}$. The reduction in $\mathrm{KCl}-\mathrm{Ca}$ was higher than in $\mathrm{KCl}-\mathrm{Mg}$. At $\mathrm{pH} 7.3$ the reduction in $\mathrm{KCl}-\mathrm{Ca}$ was an average $54 \%$ for the three soils. As expected, $\mathrm{KCl}$ exchangeable $\mathrm{Al}$ was undetected at $\mathrm{pH}>5.2$.

Effect of Al on Ca and Mg: Figure 2 shows the effect of $\mathrm{Al}$ and $\mathrm{pH}$ on the concentrations of soluble $\mathrm{Ca}$ and $\mathrm{Mg}\left(\mathrm{Ca}_{\mathrm{s}}, \mathrm{Mg}_{\mathrm{s}}\right)$. Aluminum started to reduce $\mathrm{Mg}_{\mathrm{s}}$ at $\mathrm{pH}$ higher than 8.4. This $\mathrm{pH}$ valuer agreed with that found in a solubility diagram for the formation of $\operatorname{MgAl}(\mathrm{OH})_{\mathrm{n}}$ presented by Hunsaker \& Pratt

(1970). Increasing $\mathrm{Al}$ concentration at $\mathrm{pH}>8.4$ decreased drastically $\mathrm{Mg}_{\mathrm{s}}$.

The behavior of $\mathrm{Ca}_{\mathrm{s}}$ was similar than $\mathrm{Mg}_{\mathrm{s}}$, except for the $\mathrm{pH}$ which resulted in the beginning of $\mathrm{Ca}$ precipitation (Figure 2). Precipitation of Ca started at $\mathrm{pH}$ 7.3. The reduction $\mathrm{In} \mathrm{Ca}_{\mathrm{s}}$ was higher than $\mathrm{Mg}_{\mathrm{s}}$ for similar $\mathrm{pH}$ and $\mathrm{Al} / \mathrm{M}$ molar ration, were $\mathrm{M}=\mathrm{Ca}$ or $\mathrm{Mg}$.

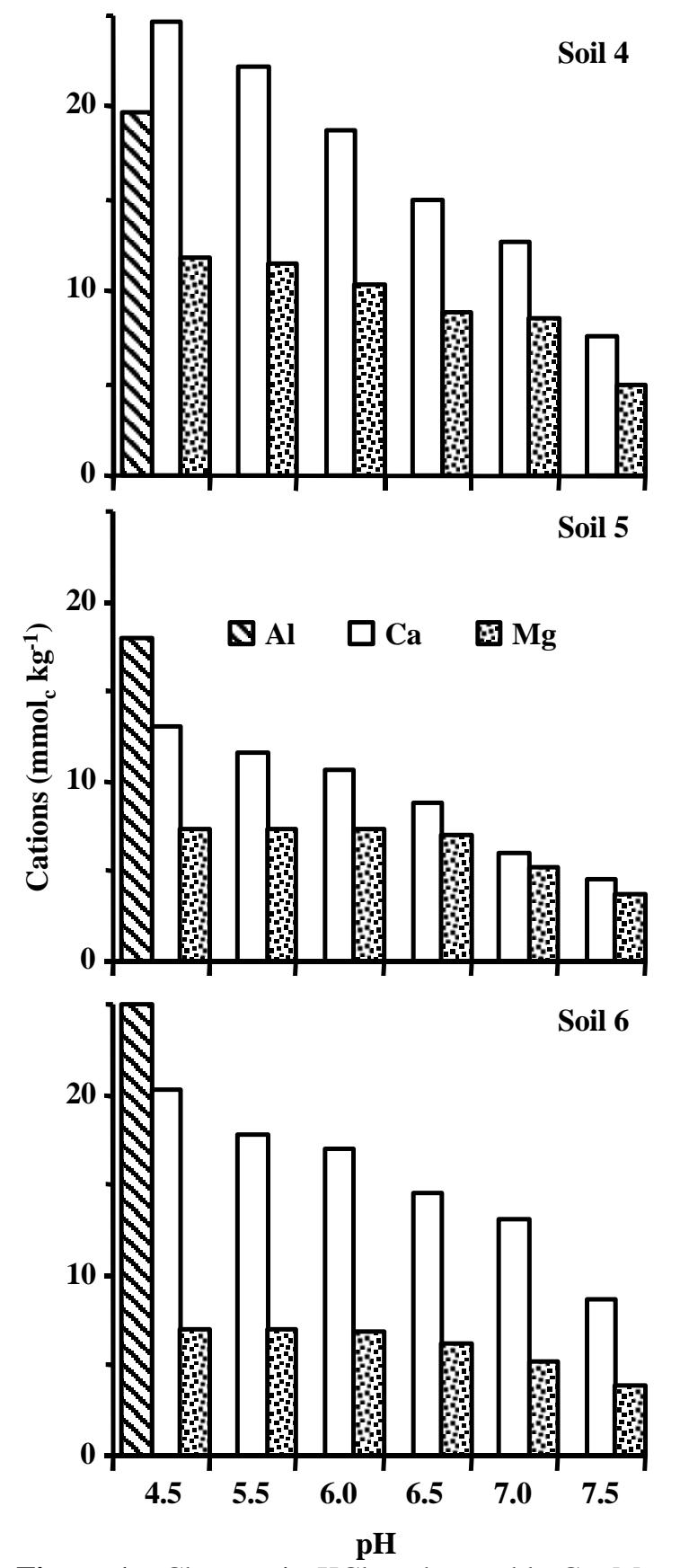

Figure 1 - Changes in $\mathrm{KCl}$ exchangeable $\mathrm{Ca}, \mathrm{Mg}$, and $\mathrm{Al}$ as function of $\mathrm{pH}$

\section{DISCUSSION}

Calcium and magnesium are alkaline earth metals with $d$ ifferent salt solubilities. In general, Casalts are less soluble that $\mathrm{Mg}$-salts. For example $\mathrm{pK}_{\mathrm{s}}$ for $\mathrm{MgCO}_{3}$ is $5.0 ; \mathrm{Mg}(\mathrm{OH})_{2}$ is $10.7 ; \mathrm{MgSO}_{4}$ is soluble; $\mathrm{CaCO}_{3}$ is $8.32 ; \mathrm{Ca}(\mathrm{OH})_{2}$ is 5.26 and $\mathrm{CaSO}_{4}$ is 5.92 (Meites, 1963). Mg precipitates in 
solution only at $\mathrm{pH}>10.5$ as $\mathrm{Mg}(\mathrm{OH})_{2}$ or at $\mathrm{pH}>$ 8.5 as $\mathrm{MgCO}_{3}$ (Lindsay, 1979).
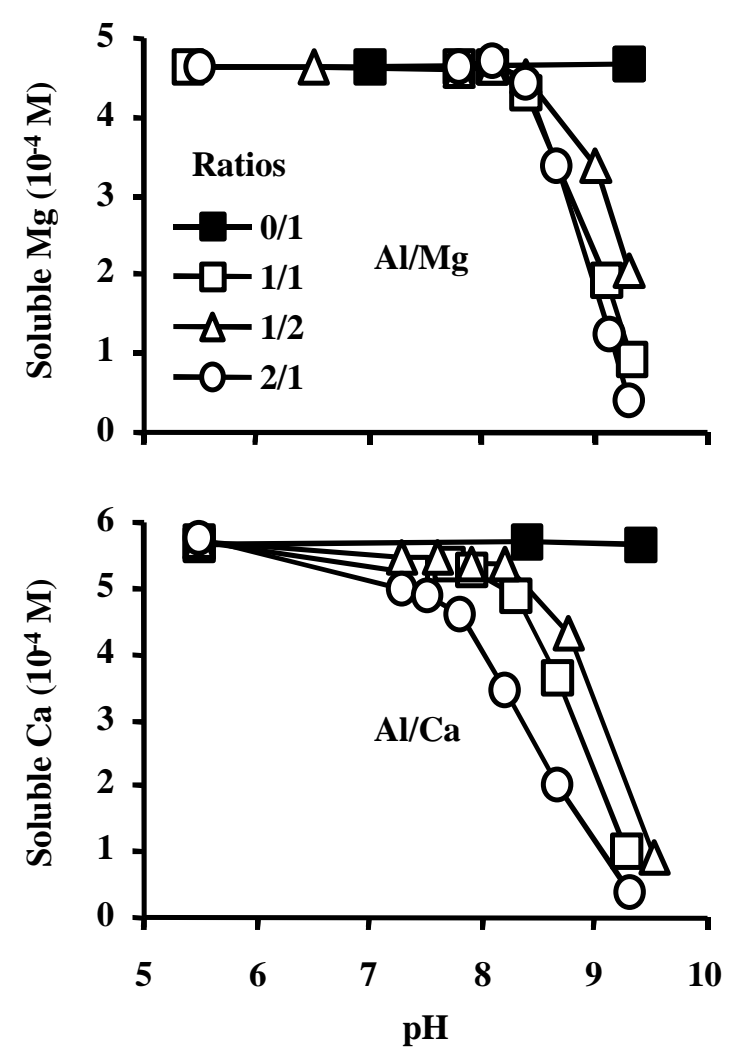

Figure 2 - Effect of $\mathrm{Al} / \mathrm{Mg}$ and $\mathrm{Al} / \mathrm{Ca}$ molar ratios on soluble $\mathrm{Ca}$ and $\mathrm{Mg}$ with varying $\mathrm{pH}$.

On the other hand, $\mathrm{Ca}$ precipitates as $\mathrm{Ca}(\mathrm{OH})_{2}$ at $\mathrm{pH}>12.5$ or as $\mathrm{CaCO}_{3}$ at $\mathrm{pH}>8.0$ in an open system $\left(0.0003\right.$ atm of $\left.\mathrm{CO}_{3}\right)$. These $\mathrm{pH}$ values are much higher than those found for the beginning of $\mathrm{Ca}_{\mathrm{ex}}$ and $\mathrm{Mg}_{\mathrm{ex}}$ reductions (Table 2 and Figure 1). Therefore, the reductions in $\mathrm{Ca}_{\mathrm{ex}}$ and $\mathrm{Mg}_{\mathrm{ex}}$ in the present study were probably due to precipitation as $\mathrm{MgCO}_{3}$ and $\mathrm{CaCO}_{3}$ or $\mathrm{Mg}(\mathrm{OH})_{2}$ and $\mathrm{Ca}(\mathrm{OH})_{2}$. Both, $\mathrm{Ca}$ and $\mathrm{Mg}$ started to precipitate at a $\mathrm{pH}$ values where $\mathrm{KCl}$ exchangeable $\mathrm{Al}$ was absent (Table 2 and Figure 1). The concentration of a dissolved ion may decrease in solution due to the formation of a coprecipitate. In other words, during the formation of an insoluble compound, estrange ions may be incorporated in the precipitate (Ohlweiler, 1976). Two types of coprecipitate are characterized: (1) adsorption: estrange ions are adsorbed on the surface of the precipitate, which are easily removed from the solid surface by a simple water percolation, common in crystalline precipitate, and (2) isomorphic: estrange ions are incorporated in the precipitate structure, which are not easily removed by solvents or other ions. This type of coprecipitation is common in amorphous precipitates, formed by metal hydroxides, such as $\mathrm{Al}^{3+}, \mathrm{Fe}^{3+}, \mathrm{Cr}^{3+}, \mathrm{Zn}^{2+}$, and others (Ohlweiler, 1976). The solubility of $\mathrm{Al}$ in solution decreased with increasing $\mathrm{pH}$ (Table 2 and Figure 1). In the $\mathrm{pH}$ range from 5.5 to $7.5, \mathrm{Al}(\mathrm{OH})_{3}$ was the principal specie (Baes \& Mesmer, 1976). The soil $\mathrm{KCl}$ exchangeable $\mathrm{Ca}_{\mathrm{ex}}$ and $\mathrm{Mg}_{\mathrm{ex}}$ started to precipitate at $\mathrm{pH} 5.2$, while in pure solution, the precipitation started at $\mathrm{pH} 7.3$ and 8.5 for $\mathrm{Ca}$ and $\mathrm{Mg}$, respectively. These differences in $\mathrm{pH}$ which $\mathrm{Ca}$ and $\mathrm{Mg}$ started to precipitate is due to different processes in the formation of $\mathrm{Al}(\mathrm{OH})_{3}$ amorphous precipitate in soil and in pure solution.

A precipitate with net negative charge is probably formed due to hydrolysis of the $\mathrm{Al}_{\mathrm{ex}}$ with increasing $\mathrm{pH}$ as shown by the following reaction:

$(\text { Soil-Al })^{2+}+30 \mathrm{H}^{-} \leftrightarrow\left[\text { Soil- } \mathrm{Al}(\mathrm{OH})_{3}\right]^{-}$

Reaction (1) favours adsorption of $\mathrm{Ca}, \mathrm{Mg}$, or other metallic cation $\left(\mathrm{M}^{++}\right)$on the surface of the precipitate. Therefore, isomorphic coprecipitate of $\mathrm{Ca}$ or $\mathrm{Mg}$ is formed in soil. Although $\mathrm{Al}$ in pure solution was also precipitated in the $\mathrm{pH}$ range from 5.5 to 7.5, $\mathrm{Ca}$ and $\mathrm{Mg}$ reductions were not detected (Figure 2). This result indicated that both cations did not form coprecipitate with amorphous $\mathrm{Al}(\mathrm{OH})_{3} \quad 3 \mathrm{H}_{2} \mathrm{O}$. The electrostatic attraction with cations was extremely low due to the neutral charge of the $\mathrm{Al}$ amorphous precipitate.

Increasing $\mathrm{pH}>7.5$ species with net negative charger are formed in solution, such as $\mathrm{Al}(\mathrm{OH})_{4}^{-}$, $\mathrm{Al}(\mathrm{OH})^{2-}{ }_{5}$, and $\mathrm{Al}(\mathrm{OH})_{6}^{3-}$. These $\mathrm{Al}$ species adsorb positive cations on the surface of the precipitate reducing $\mathrm{Ca}_{\mathrm{s}}$ and $\mathrm{Mg}_{\mathrm{s}}$. The following reactions are proposed for the reduction of $\mathrm{Mg}$.

$\mathrm{Al}(\mathrm{OH})^{-} \cdot 2 \mathrm{H}_{2} \mathrm{O}+\mathrm{Mg}_{\mathrm{s}}{ }^{2+} \rightarrow\left[\mathrm{MgAl}(\mathrm{OH})_{4} \cdot 2 \mathrm{H}_{2} \mathrm{O}\right]^{+}$

or

$\mathrm{Al}(\mathrm{OH})_{4}^{-} \cdot 2 \mathrm{H}_{2} \mathrm{O}+\mathrm{Mg}_{\mathrm{s}}{ }^{2+} \rightarrow\left\{\mathrm{Mg}\left[\mathrm{Al}(\mathrm{OH})_{4}^{-} \cdot 2 \mathrm{H}_{2} \mathrm{O}\right]_{2}\right\}$

Therefore, isomorphic coprecipitation reactions of $\mathrm{Mg}$ with Al-compounds are suggested to explain the reduction of $\mathrm{Mg}_{\mathrm{ex}}$ with increasing $\mathrm{pH}$ reported for brazilian soils (Chaves et al., 1988; Pavan et al., 1984; Pavan \& Roth, 1992). Similar reaction is believed to occur with $\mathrm{Ca}$.

Other metals $\left(\mathrm{Fe}^{3+}, \mathrm{Zn}^{2+}, \mathrm{Mg}^{2+}\right.$, and $\left.\mathrm{Cu}^{2+}\right)$ also may form isomorphic coprecipitate with $\mathrm{Ca}$ and $\mathrm{Mg}$ as 
suggested by Ohlweiler (1976). However, the concentrations of these metals in soil are so low that their contributions for $\mathrm{Ca}$ and $\mathrm{Mg}$ reductions are minimal.

\section{CONCLUSION}

The reductions of $\mathrm{KCl}$ exchangeable $\mathrm{Ca}$ and $\mathrm{Mg}$ with increasing $\mathrm{pH}$ were due to isomorphic coprecipitation with $\mathrm{Al}$ in soil as illustrate by the following reaction:

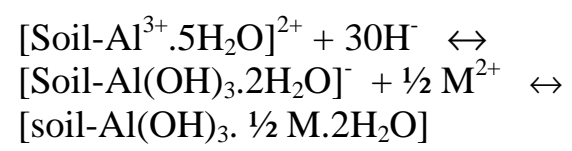

where $\mathrm{M}=\mathrm{Ca}$ or $\mathrm{Mg}$

\section{RESUMO}

Foram conduzidos experimentos de laboratório com amostras de solo e soluções sintéticas para investigar os possíveis mecanismos de reduções do $\mathrm{Ca}$ e $\mathrm{Mg}$ trocáveis com o aumento de $\mathrm{pH}$. Os aumentos no $\mathrm{pH}>5,3$ pelas adições de $\mathrm{CaCO}_{3}$ no solo e $\mathrm{NaOH}$ na suspensão solo/KCl aumentaram as adsorções de $\mathrm{Ca}$ e $\mathrm{Mg}$. A redução de $\mathrm{Mg}$ foi superior a de $\mathrm{Ca}$, sendo relacionada com a concentração de Al trocável do solo. Em soluções sintéticas cotendo $\mathrm{Al}$, as reduções de $\mathrm{Ca}$ e $\mathrm{Mg}$ ocorreram em $\mathrm{pH}>7,5$. Atribuíram-se às reações de coprecipitação isomórfica com compostos de Al, como o provável mecanismo de reduções de $\mathrm{Ca}$ e $\mathrm{Mg}$ com o aumento de pHs. São propostas as prováveis reações químicas responsáveis pelas reduções de $\mathrm{Ca}$ e $\mathrm{Mg}$ com o aumento de $\mathrm{pH}$.

\section{REFERENCES}

Baes, C. F. and Mesmer, R. E. (1976), The hydrolysis of cations. New York, John Wiley and Sons. 489p

Chan, K. Y.; Davey, B. G. and Geering, H. R. (1979), Adsorption of $\mathrm{Mg}$ and $\mathrm{Ca}$ by a soil with variable charge. Soil Sci. Soc. Am. J., 43, 301-304

Chaves, J. C. D.; Pavan, M. A. and Miyazawa, M. (1988), Redução da acidez subsuperficial em coluna de solo. Pesq. agropec. bras., 23, 469-476
Farina, M. P. W.; Sumner, M. E.; Plank, C. O. and Letzsch, W. S. (1980), Effects of $\mathrm{pH}$ o soil magnesium and its absorption by corn. Commun. Soil Sci. Pl. Anal., 11, 981-992

Grove, J. H. and Sumner, M. E. (1985), Lime induced magnesium stress in corn: impact of magnesium and phosphorus availability. Soil Sci. Soc. Am. J., 49, 1192-1196

Grove, J. H.; Sumner, M. E. and Syers, J. K. (1981), Effect of lime on exchangeable magnesium in variable surface charge soils. Soil Sci. Soc. Am. J. 45, 497-500

Hunsaker, V. E. and Pratt, P. F. (1970), The formation of mixed magnesium-alumium hydroxides in soil materials. Soil Sci. Soc. Am. Proc. 34, 813-816

Kinniburgh, D. G.; Jackson, M. L. and Syers, J. K. (1976), Adsorption of alkaline earth transition, and heavy metal cations by hydrous oxide gels of iron and aluminum Soil Sci. Soc. Am.J. , 40, 796-799

Lindsay, W. L. (1979), Chemical equilibria in soils. New York, John Wiley and Sons. 449p

Meites, L. (1963), Hand book of analytical chemistry. New York. McGraw.Hill, 1-49

Myers, J. H.; McLean, E. D. and Bingham, J. M. (1988), Reductions in exchangeable magnesium with liming of acid Ohio soils. Soil Sci. Soc. Am. J., 52, 131-136

Ohlweiler, O. H. (1976), Química analítica quantitativa. Rio de Janeiro, Livros Técnicos e Científicos, 365p

Pavan, M. A. (1992), Manejo da calagem em pomares estabelecidos de macieira. Pesq. agropec. bras., 27, 271-276

Pavan, M. A. (1997), Calcium sources for apple production in Paraná, Brasil. Ci. Cult., 49, 121-123

Pavan, M. A. and Roth, C. H. (1992), Effect of lime and gypsum on chemical composition of runoff and leachate from samples of a brazilian oxisol. Ci. Cult. 44, 391-394.

Pavan, M. A.; Bingham, F. T. and Pratt, P. F. (1984), Redistribuition of exchangeable calcium, magensium, and aluminum following lime or gypsum applications to a brazilian oxisol. Soil. Sci. Soc. Am. J., 48, 33-38

Quaggio, I. A.; Mascarenhas, H. A. A. and Bataglia, O. C. (1982), Resposta da soja à aplicação de doses crescentes de calcário em Latossolo roxo distrófico de cerrado. II. Efeito residual. Rev. Bras. Ci. Solo, 6, 113-118

Received: October 27, 1999; Revised: July 31, 2000; Accepted: August 15, 2000. 